\title{
PENGARUH PERKUATAN MORTAR JAKET DENGAN VARIASI KONFIGURASI TULANGAN LONGITUDINAL BAMBU PADA KOLOM BETON BERTULANG
}

\author{
Nurmadinah J. ${ }^{1}$, Christin Remayanti Nainggolan ${ }^{2}$, Indradi Wijatmiko ${ }^{2}$ dan Ari Wibowo ${ }^{2}$ \\ ${ }^{1}$ Mahasiswa Program Studi Sarjana / Jurusan Teknik Sipil / Universitas Brawijaya \\ ${ }^{2}$ Dosen / Jurusan Teknik Sipil / Universitas Brawijaya \\ *Korespondensi : nurmadinahj@gmail.com
}

\begin{abstract}
The Column is one of the main structures of a building. It becomes one of the structures in the portal/frame that supports beam, the entire floor load, and other loads above it. Along with the construction development, the need for transition of building function has been done a lot. To avoid a weak beam in the transition of building function, an innovation is created by reinforcing column using mortar jacketing method. In this study A5 - B5 and A6 - B6 is used for column codes. Retrofit column code A5 is the retrofit column that uses 4 pieces of bamboo longitudinal reinforcement with $10 \times 10$ millimeters size. Retrofit column code B5 uses 8 longitudinal bamboo reinforcement with $10 \times 5 \mathrm{~mm}$ size. These two columns have the same transverse reinforcement length which is $7 \mathrm{~cm}$. The retrofit column code A6 uses 4 pieces of bamboo longitudinal reinforcement with $10 \times 10 \mathrm{~mm}$ size, compared to the retrofit column code B6 that uses 8 longitudinal bamboo reinforcement with $10 \times 5 \mathrm{~mm}$ size and same transverse reinforcement that is $11 \mathrm{~cm}$. Column was tested by using a compression test machine to obtain compressive force value and dial gauge to get the deflection value. The results of the study between variations of A5 and B5 was the retrofit column B5 was more effective than retrofit column A5. While for the study between variations of A6 and B6, can be concluded that B6 variations have greater effectiveness of ductility increase of $62.33 \%$ compared to the variation of A6. It concluded that the retrofit column B6 was more effective than the retrofit column A6. Therefore, in this study reinforcement configuration has an effect on the column repairs effectiveness.
\end{abstract}

Keywords: concrete jacket, compressive force, ductility, elastic modulus, stiffness.

\section{PENDAHULUAN}

Kolom merupakan salah satu struktur utama dari suatu bangunan. Kolom menjadi salah satu struktur dalam portal/frame yang menopang balok, seluruh beban lantai, serta beban lain yang diatasnya. Oleh karena itu, dalam suatu bangunan pembuatan kolom menjadi salah satu hal yang sangat perlu diperhatikan karena jika kolom dari suatu bangunan lemah maka semua sistem struktur yang ada di atasnya pun berisiko untuk mengalami kegagalan.

Saat ini Indonesia telah mengalami perkembangan konstruksi yang semakin pesat, kebutuhan akan konstruksi bangunan pun semakin meningkat seiring dengan berjalannya waktu. Tidak hanya membangun sebuah gedung baru, namun pengembangan bangunan hingga peralihan fungsi bangunan sedang banyak dilakukan oleh masyarakat Indonesia. Dalam proses perubahan bangunan ini, tentunya diperlukan beberapa perkuatan struktur khususnya struktur kolom. Jika tidak dilakukan perkuatan, maka akan terjadi kolom lemah yang dapat mengakibatkan terjadinya kegagalan struktur. Oleh karena itu diperlukan adanya perkuatan kolom dengan menggunakan mortar jacketing yaitu metode perkuatan atau perbaikan beton dengan cara menyelimuti kolom asli dengan menggunakan lapisan tambahan berupa mortar serta penambahan tulangan menggunakan bambu petung sebagai tulangan longitudinal dan bambu apus sebagai sengkang. Hal ini dikarenakan harga bambu 
petung dan bambu apus yang relatif lebih murah, ramah lingkungan, serta mempunyai kuat tarik sejajar serat sebesar 100-400 Mpa lebih besar daripada kuat tarik baja mutu sedang.

Pengujian kolom akan menggunakan pengujian dengan beban aksial yang kemudian dilakukan identifikasi masalah guna mengetahui gaya tekan, kekakuan, modulus elastisitas, dan daktilitas yang lebih efektif dari kolom lemah yang telah diretrofit. Parameter yang ditentukan untuk mengetahui hal tersebut pada penelitian ini adalah perbedaan antar varisai jarak sengkang dan konfigurasi tulangan longitudinal bambu pada kolom lemah yang telah diretrofit.

\section{TINJAUAN PUSTAKA}

Beton bertulang merupakan beton yang diberikan tulangan dengan luas dan jumlah tulangan yang tidak kurang dari nilai minimum yang disyaratkan baik menggunakan prategang ataupun tanpa prategang, dan direncanakan berdasarkan asumsi bahwa kedua bahan tersebut bekerja sama dalam memikul gayagaya. [1]

Mortar adalah bahan bangunan yang terdiri dari agregat halus, bahan perekat serta air, dan diaduk sampai homogen [2]. Adukan mortar dibuat kelecekannya cukup baik sehingga mudah untuk dikerjakan. Sebagai bahan bangunan, mortar pun biasa diukur sifatsifatnya, misalnya kuat tekan, berat jenis, kuat tarik, daya serap air, kuat rekat dengan bata merah, susutan, dan sebagainya.

Beton bertulang adalah beton yang menggunakan tulangan dengan jumlah dan luas tulangan tidak kurang dari nilai minimum yang disyaratkan, dengan atau tanpa pratekan dan direncanakan berdasarkan asumsi bahwa kedua material bekerja bersama - sama dalam menahan gaya yang bekerja [3]. Material penyusun beton bertulang antara lain : agregat halus, agregat kasar, semen, air, dan tulangan [4].

Bambu memiliki kuat tarik yang cukup tinggi, yakni kuat tarik antara $100-400 \mathrm{Mpa}$, hampir menyamai kekuatan tarik besi tulangan setara dengan $1 / 2$ sampai $1 / 4$ dari tegangan ultimit besi. Hal ini ditampilkan pada tabel 1 . Selain itu bambu dipilih sebagai material konstruksi karena pertumbuhannya yang cepat dan mudah ditemukan.

Kuat tarik sejajar serat bambu hasil penelitian yang dilakukan oleh Morisco (1999) menunjukkan nilai yang cukup tinggi yaitu berkisar antara $2000-3000 \mathrm{~kg} / \mathrm{cm} 2$ [5].

Tabel 1. Tegangan tarik bambu kering oven tanpa nodia dan dengan nodia

\begin{tabular}{|c|c|c|}
\hline \multirow{2}{*}{ Jenis Bambu } & \multicolumn{2}{|c|}{ Tegangan Tarik (Mpa) } \\
\cline { 2 - 3 } & Tanpa Nodia & Dengan Nodia \\
\hline Ori & 291 & 128 \\
\hline Petung & 190 & 116 \\
\hline Wulung & 166 & 147 \\
\hline Tutul & 216 & 74 \\
\hline Apus & 151 & 55 \\
\hline
\end{tabular}

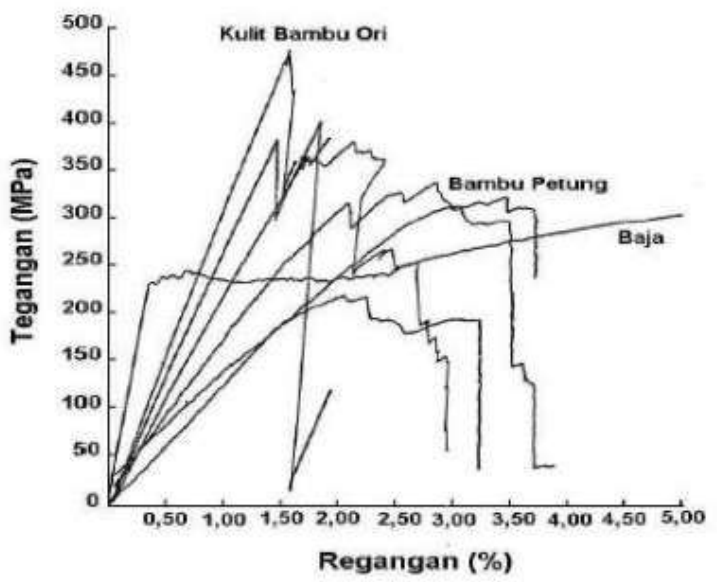

Gambar 1. Hubungan tegangan-regangan bambu dan baja.

Dari Gambar 1 tegangan-regangan bambu dan baja, diperoleh bahwa bambu ori memiliki kekuatan yang cukup tinggi yaitu hampir dua kali nilai tegangan leleh baja. Selain bambu ori, kuat tarik rata-rata dari bambu petung juga lebih besar dari tegangan leleh baja.

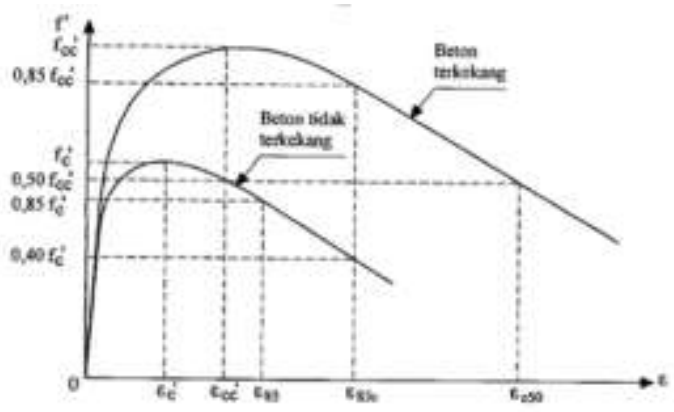

Gambar 2. Grafik gaya tekan dan deformasi material yang dibebani aksial

Tulangan longitudinal dipasang searah sumbu batang. Hasil studi yang pernah 
dilakukan menunjukkan bahwa pemasangan tulangan pada kolom beton dapat meningkatkan kekuatan dan daktilitasnya. Oleh karena itu, untuk tetap mempertahankan kekuatan dan daktilitas pada daerah momen maksimum kolom,beton pada daerah inti harus memperoleh kekangan yang cukup.

Pada pemasangan konfigurasi tulangan longitudinal dengan variasi yang berbeda, akan menimbulkan 2 macam kondisi yang terjadi pada kolom. Pertama ialah perilaku kekangan kolom akibat dari efektifitas kekangan dan yang kedua ialah perilaku kolom akibat dari tekuk terjadi pada tulangan longitudinal. Efektifitas kekangan dari kolom erat kaitannya dengan pengaruh luas efektif yang tidak mengalami kekangan. Semakin kecil luas daerah yang tidak mengalami kekangan, maka hal ini akan meningkatkan daktilitas dari kolom. Sedangkan untuk perilaku tekuk tulangan longitudinal, dipengaruhi oleh rasio tekuk tulangan yang diperoleh dengan membagi antara luas penampang tulangan dengan panjang tulangan yang tidak mengalami kekangan, semakin besar rasio tekuk tulangan, maka semakin kuat sebuah kolom untuk menahan beban aksial yang ada.

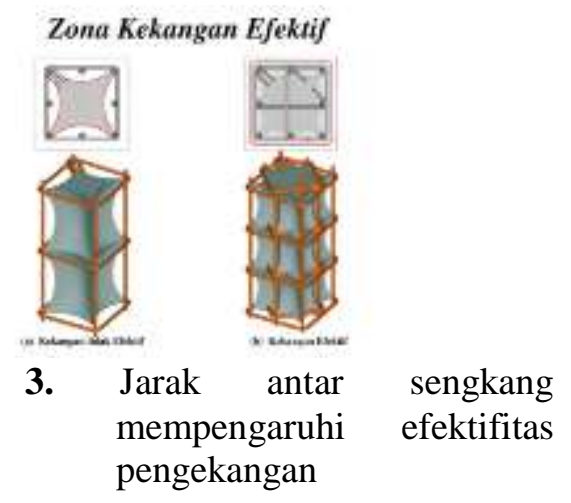

\subsection{Kuat Beban Aksial Kolom}

Rumus kolom bertulang baja dapat dilihat pada persamaan (1)

$P_{n(\max )}=0.85 f^{\prime}{ }_{c}\left(A_{g}-\right.$

$\left.A_{s t}\right)+(f y . A s t)$.

Rumus kolom retrofit bertulang bambu dapat dilihat pada persamaan (2)

$$
\begin{aligned}
& P_{n(\max )}=f^{{ }^{\prime \prime}}{ }_{c} \times \mathrm{Ag} \\
& f^{\prime{ }_{c}} \quad=K f_{c}{ }^{\prime} \ldots \ldots \\
& K \quad=1+\frac{\rho_{s f_{y h}}}{f_{c^{\prime}}}
\end{aligned}
$$

Sumber : [6]
Keterangan :

Pn = kuat beban aksial nominal pada eksentrisitas yang diberikan $(\mathrm{kN})$

$\mathrm{Ag}=$ luas penampang bruto beton $\left(\mathrm{mm}^{2}\right)$

Ast $=$ luas tulangan $\left(\mathrm{mm}^{2}\right)$

$\mathrm{f}^{\prime}$ 'c $=$ Tegangan Maksimum Beton (MPa)

$\mathrm{f}^{\prime} \mathrm{c}=$ kuat tekan beton $(\mathrm{MPa})$

fy $=$ tegangan leleh dari tulangan longitudinal (MPa)

fyh = tegangan leleh dari tulangan transversal (MPa)

$\rho s=$ Rasio tulangan trasversal

\subsection{Tegangan dan Regangan Kolom}

Rumus tegangan pada kolom bertulang dapat dilihat pada persamaan (3).

$\sigma=\frac{P}{A}$

Keterangan :

$P=$ gaya tekan $(\mathrm{kN})$

$A=$ luas tampang melintang $\left(\mathrm{mm}^{2}\right)$

Rumus regangan pada kolom bertulang dapat dilihat pada persamaan (4).

$\varepsilon=\frac{\Delta L}{L}$

Keterangan :

$\Delta L=$ perubahan panjang akibat beban $\mathrm{P}(\mathrm{mm})$

$L=$ panjang semula $(\mathrm{mm})$

\subsection{Kekakuan dan Modulus Elastisitas Kolom}
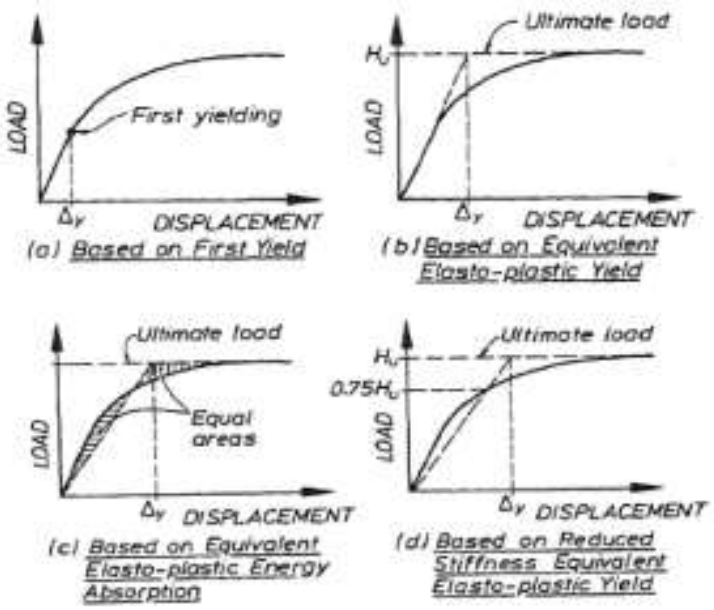

Gambar 4. Beberapa Alternatif Pengambilan Lendutan pada Titik Leleh Sumber : [6]

Menurut Park [6] lendutan pada titik leleh dapat diambil dari titik potong beban yang mana beban diambil $75 \%$ dari beban ultimate. 
Rumus kekakuan dapat dilihat pada persamaan (5).

$k=\frac{P}{\Delta}$

Keterangan :

$\mathrm{k}=$ Kekakuan Struktur $(\mathrm{kN} / \mathrm{mm})$

$\mathrm{P} \quad=$ Gaya Tekan $(\mathrm{kN})$

$\Delta \quad=\operatorname{Defleksi}(\mathrm{mm})$

Pada analisis data untuk mencari nilai kekakuan kolom asli dan kolom retrofit menggunakan metode yang dilakukan oleh Park (1988) yakni, untuk nilai gaya tekan dapat diambil dari $75 \%$ dari nilai gaya tekan maksimum dan nilai defleksi diambil pada $75 \%$ dari nilai gaya tekan maksimum.

Rumus modulus elastisitas dapat dilihat pada persamaan (6).

$E=\frac{\sigma}{\varepsilon}$.

Keterangan :

$\mathrm{E} \quad=$ Modulus Elastisitas $\left(\mathrm{kN} / \mathrm{mm}^{2}\right)$

$\sigma \quad=$ Tegangan $\left(\mathrm{kN} / \mathrm{mm}^{2}\right)$

$\varepsilon \quad=$ Regangan

Pada analisis data untuk mencari nilai modulus elastisitas kolom asli dan kolom retrofit, nilai tegangan diperoleh dari $75 \%$ dari nilai gaya tekan maksimum dibagi dengan luas penampang kolom serta nilai regangan diambil dari nilai defleksi dari $75 \%$ gaya tekan maksimum dibagi dengan panjang mula - mula kolom yakni $300 \mathrm{~mm}$.

\subsection{Daktilitas Kolom}

Daktilitas adalah sifat dari suatu bahan yang dapat melalui perubahan bentuk secara permanen tanpa adanya kerusakan. Daktilitas atau keuletan diperlukan pada proses perencanaan beban terhadap suatu bahan guna mencegah kerusakan yang tidak terdeteksi apabila suatu bahan menerima beban yang besar secara tiba-tiba

Rumus daktilitas dapat dilihat pada persamaan (7).

$\mu_{\Delta=\frac{\Delta u}{\Delta y}}$.

Keterangan :

$\mu \Delta=$ Nilai daktilitas

$\Delta \mathrm{u}=$ Deformasi ultimate $(\mathrm{cm})$

$\Delta \mathrm{y}=$ Deformasi leleh $(\mathrm{cm})$
3. METODOLOGI PENELITIAN

Tabel 2. Vvariasi tulangan bambu pada kolom retofit

\begin{tabular}{|c|c|c|c|c|}
\hline \multirow{2}{*}{$\begin{array}{c}\text { Kode } \\
\text { Kolom }\end{array}$} & \multirow{2}{*}{$\begin{array}{c}\text { Tulangan } \\
\text { Bambu }\end{array}$} & \multirow{2}{*}{ rho } & \multicolumn{2}{|c|}{ Sengkang bambu } \\
\cline { 4 - 5 } & & & $\mathbf{5}$ & $\mathbf{6}$ \\
\cline { 4 - 5 } & & Jarak 7 cm & Jarak $11 \mathrm{~cm}$ \\
\hline $\mathrm{A}$ & 4 bh $10 \times 10$ & 1,23 & 3 buah & 3 buah \\
\hline $\mathrm{B}$ & 8 bh $10 \times 5$ & 1,23 & 3 buah & 3 buah \\
\hline
\end{tabular}

Tabel 3. Jumlah benda uji

\begin{tabular}{|c|c|}
\hline Varian & Jumlah \\
\hline Benda uji silinder sampel kolom asli & 4 buah \\
\hline Benda uji kolom asli & 12 buah \\
\hline Benda uji silinder sampel kolom retrofit & 4 buah \\
\hline Benda uji kolom retrofit kode A5 & 3 buah \\
\hline Benda uji kolom retrofit kode B5 & 3 buah \\
\hline Benda uji kolom retrofit kode A6 & 3 buah \\
\hline Benda uji kolom retrofit kode B6 & 3 bush \\
\hline
\end{tabular}

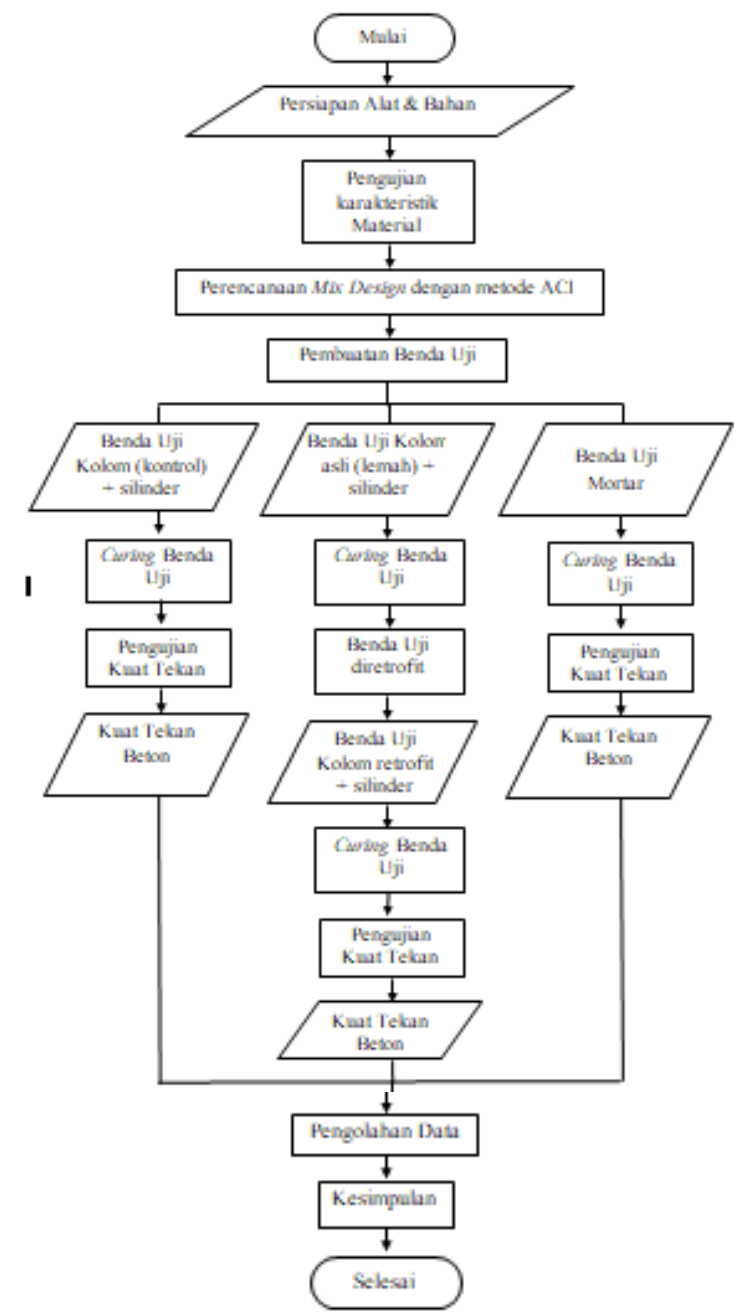

Gambar 4. Diagram alir tahapan penelitian 


\section{HASIL DAN PEMBAHASAN}

Pada pengujian kuat tekan beton silinder diambil 2 benda uji kuat tekan setiap variasi kolom. Hasil uji tekan beton silinder dapat dilihat pada Tabel 4 dan Tabel 5. Sedangkan hasil uji kuat tekan mortar dapat dilihat pada Tabel 6.

Tabel 4. Hasil uji kuat tekan beton benda uji silinder (sampel benda uji kolom asli)

\begin{tabular}{cccccc}
$\begin{array}{c}\text { Kode Benda } \\
\text { Uji }\end{array}$ & Umur & Berat & $\begin{array}{c}\text { Beban } \\
\text { Maksimum }\end{array}$ & $\begin{array}{c}\text { Gaya } \\
\text { Tekan }\end{array}$ & $\begin{array}{c}\text { Gaya Tekan } \\
\text { Rata-Rata }\end{array}$ \\
\cline { 2 - 6 } & (Hari) & $(\mathrm{kg})$ & $(\mathrm{kN})$ & $(\mathrm{Mpa})$ & $(\mathrm{Mpa})$ \\
\hline A5 -A6 (1) & & 12,30 & 382,3 & 21,63 & 17,95 \\
A5 -A6 (2) & 28 & 12,55 & 252,1 & 14,27 & \\
B5 -B6 (1) & 28 & 12,45 & 321,0 & 18,16 & 21,06 \\
B5 -B6 (2) & & 12,50 & 423,3 & 23,95 & \\
\hline
\end{tabular}

Tabel 5. Hasil uji kuat tekan beton benda uji silinder (sampel benda uji kolom kontrol)

\begin{tabular}{cccccc}
\hline \multirow{2}{*}{$\begin{array}{c}\text { Kode Benda } \\
\text { Uji }\end{array}$} & Slump & Berat & $\begin{array}{c}\text { Beban } \\
\text { Maksimum }\end{array}$ & $\begin{array}{c}\text { Gaya } \\
\text { Tekan }\end{array}$ & $\begin{array}{c}\text { Gaya Tekan } \\
\text { Rata-Rata }\end{array}$ \\
\cline { 2 - 6 } & & & & & \\
\hline Kontrol & 11 & 12,4 & 242,6 & 13,73 & 13,73 \\
\hline
\end{tabular}

Tabel 6. Hasil uji kuat tekan beton benda uji mortar (sampel benda uji kolom retrofit)

\begin{tabular}{|c|c|c|c|c|c|c|}
\hline \multirow[t]{2}{*}{ No } & \multirow{2}{*}{$\begin{array}{c}\text { Koda Benda } \\
\quad \mathrm{Uji}\end{array}$} & \multirow{2}{*}{$\begin{array}{l}\text { Umur } \\
\text { (Hari) }\end{array}$} & Berat & $\begin{array}{c}\text { Beban } \\
\text { Maksimum }\end{array}$ & Gaya Tekan & \multirow{2}{*}{$\begin{array}{c}\text { Gaya Telkan Rata- } \\
\text { Rata } \\
\text { (Mpa) }\end{array}$} \\
\hline & & & (kg) & (kN) & (Mpa) & \\
\hline \multirow{3}{*}{1} & A5 (1) & \multirow{12}{*}{28} & 304,30 & 62,00 & 24,80 & \multirow{3}{*}{22,56} \\
\hline & A5 (2) & & 290,10 & 40,00 & 16,00 & \\
\hline & A5 (3) & & 331,60 & 67,20 & 26,88 & \\
\hline \multirow{4}{*}{2} & A6 (1) & & 285,10 & 68,50 & 27,40 & \multirow{4}{*}{32,33} \\
\hline & A6 (2) & & 276,30 & 74,00 & 29,60 & \\
\hline & A6 (3) & & 279,70 & 100,00 & 40,00 & \\
\hline & B5 (1) & & 281,00 & 104,00 & 41,60 & \\
\hline \multirow[t]{3}{*}{3} & B5 (2) & & 272,90 & 72,40 & 28,96 & \multirow[t]{3}{*}{33,25} \\
\hline & B5 (3) & & 292,00 & 73,00 & 29,20 & \\
\hline & B6 (1) & & 272,90 & 58,60 & 23,44 & \\
\hline \multirow[t]{2}{*}{4} & B6 (2) & & 281,40 & 70,20 & 28,08 & \multirow[t]{2}{*}{26,19} \\
\hline & B6 (3) & & 259,50 & 67,60 & 27,04 & \\
\hline
\end{tabular}

Pada pengujian kuat beban aksial kolom asli dan kolom retrofit dapat dilihat pada Tabel 7, Tabel 8, dan Tabel 9.

Tabel 7. Tabel hasil kuat beban aksial kolom asli secara teoritis (tidak dilakukan pengujian beban aksial)

\begin{tabular}{cccc}
\hline \multirow{2}{*}{ No } & $\begin{array}{c}\text { Kode Benda } \\
\text { Uji Kolom Asli }\end{array}$ & $\begin{array}{c}\text { Gaya Telan Beton } \\
\text { (fc) }\end{array}$ & $\begin{array}{c}\text { Keluatan Nominal Kolom } \\
\text { (Pn) Secara Teoritis }\end{array}$ \\
\cline { 3 - 4 } & & (Mpa) & kN \\
\hline 1 & A5 & 17,95 & 248,01 \\
2 & A6 & 17,95 & 248,01 \\
3 & B5 & 21,06 & 285,86 \\
4 & B6 & 21,06 & 285,86 \\
\hline
\end{tabular}

Tabel 8. Tabel hasil kuat beban aksial kolom kontrol

\begin{tabular}{|c|c|c|c|c|}
\hline No & $\begin{array}{c}\text { Kode } \\
\text { Benda } \\
\text { Uji }\end{array}$ & $\begin{array}{l}\text { 'Kuat Telran } \\
\text { Beton (fe') }\end{array}$ & $\begin{array}{c}\text { Kuat Telsan } \\
\text { Kolom Asli } \\
\text { Malssimum } \\
\text { Teoritis }\end{array}$ & $\begin{array}{c}\text { Kelkuatan } \\
\text { Maksimum } \\
\text { Kolom (Pu) } \\
\text { Secara Aktual }\end{array}$ \\
\hline & & (Mpa) & $(\mathrm{kN})$ & $(\mathrm{kN})$ \\
\hline 1 & Kontrol & 13,73 & 196,62 & 270,20 \\
\hline
\end{tabular}

Tabel 9. Tabel hasil kuat beban aksial kolom retrofit

\begin{tabular}{ccccc}
\hline \multirow{2}{*}{ No } & $\begin{array}{c}\text { Kode } \\
\text { Benda Uji } \\
\text { Kolom } \\
\text { Retrofit }\end{array}$ & $\begin{array}{c}\text { Gaya Tekan } \\
\text { Beton (fC) }\end{array}$ & $\begin{array}{c}\text { Kelkatan Nominal } \\
\text { Kolom (Pn) Secara } \\
\text { Teoritis }\end{array}$ & $\begin{array}{c}\text { Keluatan } \\
\text { Malssimum } \\
\text { Kolom (Pu) } \\
\text { Secara Aktual }\end{array}$ \\
\cline { 3 - 5 } & A5 & 22,56 & kN & kN \\
\hline 1 & A5 & 32,33 & 479,313 & 437,05 \\
2 & A6 & 33,678 & 431,94 \\
3 & B5 & 33,25 & 539,070 & 393,21 \\
4 & B6 & 26,19 & 455,359 & 401,20 \\
\hline
\end{tabular}

Dari penelitian yang telah dilakukan pada kuat beban aksial kolom asli dengan kolom retrofit didapatkan hasil kuat beban aksial maksimum pada kolom asli yang dinyatakan dengan menggunakan kuat beban aksial maksimum kolom kontrol yaitu dapat dilihat pada tabel 8 sebesar 270,2 kN. Sedangkan hasil kuat beban aksial maksimum pada kolom retrofit dapat dilihat pada tabel 9, yaitu kolom retrofit A5 sebesar 437,29 kN, jadi dapat disimpulkan bahwa terjadi peningkatan kuat beban aksial maksimum kolom retrofit A5 sebesar $61,75 \%$ dari kuat beban aksial maksimum kolom kontrol. Kolom retrofit A6 sebesar 432,60 kN, jadi dapat disimpulkan bahwa terjadi peningkatan pada kuat beban aksial kolom retrofit A6 sebesar 59,86\% dari kuat beban aksial maksimum kolom kontrol. Kolom retrofit B5 diperoleh sebesar 394,69 kN, jadi dapat disimpulkan bahwa terjadi peningkatan pada kuat beban aksial kolom retrofit B5 sebesar 45,52\% dari kuat beban aksial maksimum kolom kontrol. Kolom retrofit B6 sebesar 408,72 kN, jadi dapat disimpulkan bahwa terjadi peningkatan pada kuat beban aksial kolom retrofit B6 sebesar $48,48 \%$ dari kuat beban aksial maksimum kolom kontrol.

Tabel 10. Tabel perbandingan hasil penelitian kolom retrofit A5 dengan kolom retrofit B5

\begin{tabular}{|c|c|c|c|c|c|c|c|c|}
\hline \multirow[t]{2}{*}{ No } & \multirow{2}{*}{$\begin{array}{c}\text { Kode } \\
\text { Benda } \\
\text { Uji } \\
\text { Kolom }\end{array}$} & \multicolumn{2}{|c|}{$\begin{array}{c}\text { Gaya Teksan } \\
\text { Makssimum } \\
\text { (kN) }\end{array}$} & \multicolumn{2}{|c|}{$\begin{array}{l}\text { Kelkakuan } \\
(\mathrm{kN} / \mathrm{mm})\end{array}$} & \multicolumn{2}{|c|}{$\begin{array}{l}\text { Modulus } \\
\text { Elastisitas } \\
\left(\mathrm{kN} / \mathrm{mm}^{2}\right)\end{array}$} & \multirow[t]{2}{*}{$\begin{array}{l}\text { Peningkatan } \\
\text { Daktilitits } \\
\text { (\%) }\end{array}$} \\
\hline & & Kontrol & Retrofit & Kontrol & & Kontrol & Retrofit & \\
\hline 1 & A5 & 270,20 & & 156,07 & 204,09 & 3,0228 & 4,25 & $\begin{array}{l}4,2519 \\
3,4655\end{array}$ \\
\hline
\end{tabular}


Tabel 11. Tabel perbandingan efektifitas kolom A5 dengan kolom retrofit B5

\begin{tabular}{cccccc}
\hline No & $\begin{array}{c}\text { Kode Benda } \\
\text { Uji Kolom }\end{array}$ & $\begin{array}{c}\text { Peningkatan } \\
\text { Gaya Teksn } \\
\text { Malssimum } \\
(\%)\end{array}$ & $\begin{array}{c}\text { Efektifitas } \\
\text { Gays Telsan } \\
(\%)\end{array}$ & $\begin{array}{c}\text { Peningkatan } \\
\text { Dalktilitas } \\
(\%)\end{array}$ & $\begin{array}{c}\text { Efektifitas } \\
\text { Dalktilitas } \\
(\%)\end{array}$ \\
\hline 1 & A5 & 61,78 & $-26,27$ & 60,65 & 0,33 \\
\hline & B5 & 45,55 & $-26,85$ & 0,35 \\
\hline
\end{tabular}

Berdasarkan data yang diperoleh pada Tabel 10 dan Tabel 11, maka diperoleh kesimpulan bahwa berdasarkan parameter kuat tekan maksimum atau kemampuan aksial kolom, maka kolom retrofit A5 lebih efektif dalam penggunaannya dibandingkan dengan kolom retrofit B5, hal ini dikarenakan efektifitas peningkatan gaya tekan kolom retrofit B5 lebih rendah sebesar 26,27\% dibandingkan kolom retrofit A5. Namun, daktilitas yang dimiliki kolom retrofit B5 sedikit lebih tinggi dibandingkan dengan kolom retrofit A5, dimana kolom retrofit B5 memiliki efektifitas lebih besar sebesar $0,33 \%$ dibandingkan kolom retrofit A5.

Hal ini dikarenakan karena kolom retrofit B5 memiliki konfigurasi tulangan longitudinal yang lebih rapat, sehingga efek kekangan yang diberikan oleh kolom retrofit B5 sedikit lebih besar dibandingkan dengan kolom retrofit A5 dan membuat kolom retrofit B5 memiliki waktu yang lebih lama sebelum mengalami kehancuran. Oleh karena itu, jika menilai dari efektifitas kekangan kolom, maka kolom retrofit B5 lebih efektif digunakan dalam perbaikan ini.

Tabel 12. Tabel perbandingan hasil penelitian kolom retrofit A6 dengan kolom retrofit B6

\begin{tabular}{|c|c|c|c|c|c|c|c|c|}
\hline \multirow[t]{2}{*}{ No } & \multirow{2}{*}{$\begin{array}{c}\text { Kode } \\
\text { Benda } \\
\text { Uji } \\
\text { Kolom }\end{array}$} & \multicolumn{2}{|c|}{$\begin{array}{l}\text { Gaya Telan } \\
\text { Maksimum } \\
\text { (k-N) }\end{array}$} & \multicolumn{2}{|c|}{$\begin{array}{l}\text { Kelkakuan } \\
(\mathrm{kNN} / \mathrm{mm})\end{array}$} & \multicolumn{2}{|c|}{$\begin{array}{l}\text { Modulus } \\
\text { Elastisitas } \\
\left(\mathrm{kN} / \mathrm{mm}^{2}\right)\end{array}$} & \multirow[t]{2}{*}{$\begin{array}{c}\text { Peningkatan } \\
\text { Daktilitas } \\
\text { (\%) }\end{array}$} \\
\hline & & Kontrol & Retrofit & Kontrol & Retrofit & Kontrol & Retrofit & \\
\hline $\begin{array}{l}1 \\
2\end{array}$ & $\begin{array}{l}\text { A6 } \\
\text { B6 }\end{array}$ & 270,20 & $\begin{array}{c}431,94 \\
401,201\end{array}$ & 156,07 & $\begin{array}{l}175,64 \\
175,99\end{array}$ & 3,0228 & $\begin{array}{l}3,46 \\
3,67\end{array}$ & $\begin{array}{l}26,84 \\
43,57\end{array}$ \\
\hline
\end{tabular}

Tabel 13. Tabel perbandingan efektifitas kolom A6 dengan kolom retrofit B6

\begin{tabular}{cccccc}
\hline No & $\begin{array}{c}\text { Kode } \\
\text { Benda } \\
\text { Uji } \\
\text { Kolom }\end{array}$ & $\begin{array}{c}\text { Peninglatan Telsan } \\
\text { Maksimum } \\
(\%)\end{array}$ & $\begin{array}{c}\text { Efeltifitas } \\
\text { Gaya Telsan } \\
(\%)\end{array}$ & $\begin{array}{c}\text { Peningkatan } \\
\text { Daltilitas } \\
(\%)\end{array}$ & $\begin{array}{c}\text { Efektifitas } \\
\text { Daktilitas } \\
(\%)\end{array}$ \\
\hline 1 & A6 & 59,89 & $-19,02 \%$ & $26,84 \%$ & $62,33 \%$ \\
2 & B6 & 48,51 & & $43,57 \%$ & $62,33 \%$ \\
\hline
\end{tabular}

Berdasarkan data yang diperoleh pada Tabel 12 dan Tabel 13, maka diperoleh kesimpulan bahwa berdasarkan parameter kuat tekan maksimum atau kemampuan aksial kolom, maka kolom retrofit A6 lebih efektif dalam penggunaannya dibandingkan dengan kolom retrofit $\mathrm{B} 6$, hal ini dikarenakan efektifitas peningkatan gaya tekan kolom retrofit B6 lebih rendah sebesar 19,02\% dibandingkan kolom retrofit A6.

Namun, daktilitas yang dimiliki kolom A6 lebih kecil dibandingkan dengan kolom retrofit B6, dimana kolom B6 memiliki efektifitas lebih besar sebesar 62,33\% dibandingkan kolom retrofit A6. Hal ini dikarenakan karena kolom retrofit B6 memiliki konfigurasi tulangan longitudinal yang lebih rapat, sehingga efek kekangan yang diberikan oleh kolom B6 lebih besar dibandingkan dengan kolom retrofit A6. Oleh karena itu, jika mengacu dari efektifitas kekangan kolom, maka kolom retrofit B6 lebih efektif digunakan dalam perbaikan ini.

Berdasarkan hasil tersebut, maka diperoleh kesimpulan bahwa kolom retrofit B6 lebih efektif dibandingkan dengan kolom retrofit A6, hal ini dikarenakan efektifitas peningkatan daktilitas B6 jauh lebih tinggi dibandingkan A6.

\section{PENUTUP}

\subsection{Kesimpulan}

Dari hasil penelitian dan pembahasan yang telah diuraikan, maka dapat diambil kesimpulan sebagai berikut :

1. Dari hasil penelitian perbandingan antara variasi kolom retrofit A5 dan B5 diperoleh bahwa kolom retrofit B5 memiliki efektifitas peningkatan gaya tekan maksimum yang lebih rendah sebesar 26,27\% dibandingkan kolom retrofit A5. Sedangkan untuk perbandingan antara variasi A6 dan B6 diperoleh bahwa variasi B6 memiliki nilai efektifitas peningkatan gaya tekan maksimum yang lebih rendah sebesar 19,02\% dibandingkan variasi A6.

2. Berdasarkan hasil penelitian perbandingan antara variasi kolom retrofit A5 dan B5 diperoleh bahwa kolom retrofit B5 memiliki nilai kekakuan dan modulus elastisitas yang lebih kecil masing-masing sebesar $61,17 \%$ dan $49,79 \%$ dibandingkan kolom retrofit A5. Dan pada perbandingan kolom retrofit A6 dan B6 diperoleh bahwa kolom retrofit B6 memiliki nilai kekakuan dan modulus elastisitas yang lebih besar 
masing-masing sebesar $1,82 \%$ dan $45,43 \%$ dibandingkan kolom A6. Sedangkan berdasarkan nilai efektifitas peningkatan daktilitas diperoleh bahwa kolom retrofit B5 memiliki nilai efektifitas peningkatan daktilitas yang sedikit lebih besar sebesar $0,33 \%$ dibandingkan kolom retrofit A5. Namun untuk kolom retrofit B6 memiliki efektifitas peningkatan daktilitas lebih besar sebesar $62,33 \%$ dibandingkan kolom retrofit A6.

3. Untuk nilai efektifitas kekangan dari konfigurasi tulangan longitudinal kolom dapat diperoleh dari pengaruh nilai gaya tekan maksimum dan daktilitas dari masing-masing variasi kolom retrofit yang telah dibandingkan, hal ini karena nilai kekakuan dan modulus elastisitas dari kolom akan selalu berbanding lurus dengan gaya tekan maksimum dari kolom, jika gaya tekan maksimum dari kolom retrofit mengalami kenaikan maka kekakuan dan modulus elastisitas kolom retrofit akan mengalami kenaikan pula, begitupun sebaliknya. Namun, dalam penelitian ini karena penampang kolom asli maupun kolom retrofit yang diuji sama, maka efektifitas kekangan akan lebih dipengaruhi oleh daktilitas dari kolom retrofit, bukan dari peningkatan gaya tekan maksimum kolom. Maka berdasarkan hasil penelitian yang telah dilakukan, disimpulkan bahwa untuk perbandingan antara variasi kolom retrofit A5 dan B5 diperoleh bahwa kolom retrofit B5 memiliki efektifitas yang lebih baik, karena memiliki peningkatan daktilitas yang lebih besar dibandingkan dengan kolom retrofit A5. Selanjutnya untuk perbandingan antara kolom retrofit A6 dan B6 diperoleh bahwa kolom retrofit B6 memiliki efektifitas yang lebih baik, karena memiliki peningkatan daktilitas yang lebih besar pula dibandingkan dengan kolom retrofit A6.

\subsection{Saran}

Saran yang bisa diberikan peneliti untuk penelitian selanjutnya sebagai berikut :

1. Dalam penelitian kolom dengan initial condition, diperlukan penambahan jumlah kolom kontrol. Disarankan untuk setiap variasi kolom asli memiliki benda uji kolom kontrol yang akan digunakan sebagai perbandingan dalam nilai gaya tekan maksimum kolom. Hal ini dilakukan agar nilai gaya tekan maksimum untuk setiap kolom asli yang tidak diuji lebih akurat untuk dibandingkan nantinya.

2. Untuk ukuran dimensi kolom retrofit diperbesar agar mudah dalam pembuatan benda uji kolom retrofit sehingga tidak ada rongga pada kolom retrofit ketika bekisting dibuka karena pada penelitian ini jarak antara kolom asli dengan kolom retrofit masih terlalu kecil, dan sulit dalam proses pengecorannya.

3. Dalam melakukan pengujian, khususnya uji kuat tekan yang memerlukan pembacaan dial, diperlukan untuk menyiapkan alat dokumentasi lebih dari 1, hal ini untuk menghindari terjadinya hal yang tidak diinginkan pada proses perekaman video, seperti memori alat dokumentasi yang telah penuh sementara proses pengujian masih berjalan.

4. Dalam melakukan penelitian ini, kualitas dan mutu dari material yang digunakan perlu diperhatikan sebelum dilakukan pengecoran. Selain itu, pelaksanaan penegecoran pun perlu diperhatikan agar tidak terjadi kesalahan dalam proses penelitian. Hal ini dikarenakan pada pengecoran mortar, diperoleh nilai kuat tekan yang jauh dari nilai rencana kuat tekan seharusnya, hal ini mungkin saja terjadi karena perbedaan kualitas material yang digunakan ataupun metode yang digunakan pada proses pengecoran.

\section{DAFTAR PUSTAKA}

[1] Ashar, Ahmad. 2016. Perkuatan Kolom Beton Dengan Metode Jacketing Menggunakan Tulangan Bambu. Surakarta : Universitas Muhammadiyah Surakarta.

[2] Wuryati, S. \& Candra, R. 2001. Teknologi Beton. Yogyakarta: Kansius.

[3] Mulyono, Tri. (2004). Teknologi Beton. Penerbit ANDI. Yogyakarta

[4] SNI 03-2847-2002. 2002. Tata Cara Perhitungan Struktur Beton Untuk Bangunan Gedung. Jakarta : Badan Standarisasi Nasional.

[5] Morisco. 1999. Rekayasa Bambu. Nafiri Offset. Yogyakarta.

[6] Park,R \& Paulay,T. 1974. Reinforced Concrete Structures. New Zealand : Departement of Civil Engineering, University of Canterbury. 